\title{
Accounting as a Choice of Academic Programme: A Comparative Study between Malaysian and Indonesian First-year Under-graduate Accounting Students
}

\author{
Maheran Zakaria ${ }^{1, *}$, Muhammad Saiful Anuar Yusoff ${ }^{1}$, Ida Rosnidah Rozak ${ }^{2}$ \\ ${ }^{1}$ Universiti Teknologi MARA Kelantan, Malaysia \\ ${ }^{2}$ Universitas Swadaya Gunung Jati, Indonesia
}

Received September 7, 2019; Revised October 10, 2019; Accepted October 17, 2019

Copyright@2019 by authors, all rights reserved. Authors agree that this article remains permanently open access under the terms of the Creative Commons Attribution License 4.0 International License

\begin{abstract}
Although rapid and tremendous economy development worldwide has sparked a massive demand for accountants, developing nations like Malaysia and Indonesia are dearth of this profession. Triggered by this mismatch and emulating variables postulated by Theory of Reasoned Action, the objectives of this study are to decipher intention to choose accounting as academic programme with regards to attitude towards accounting profession and social group influence in Malaysian and Indonesian contexts. A total of 350 Malaysian and 150 Indonesian under-graduate accounting students participated in the study. Data were analysed using Sequential Equation Modelling (SEM) of Smart Partial Least Square (PLS) version three. Results for both nations indicated that the attitude towards accounting programme and social group influence were more likely to affect student's intention to choose accounting as academic programme. The former perceived that the paramount prospect offered by the profession is good long-term income, while the later believed that it is broad job opportunities. Likewise, students for both nations were more likely motivated to comply with the expectations of family, followed by teachers, friends, counsellors and peers. These discoveries provide useful insights for policy makers, accounting professional bodies and higher education to formulate policies exposing students and social groups on the importance of incentives and prospects of the accounting profession. It is hoped that the initiatives will produce many accountants and thus expedites the countries' aspiration of becoming full-developed nations in due time.
\end{abstract}

Keywords Accounting, Programme, Attitude, Indonesia, Malaysia, Social Influence, Students

\section{Introduction}

Learning is a life-long journey that takes place on an ongoing, voluntary and self-motivated basis in pursuit of knowledge enhancement. People learn for self-sustainability, personal and professional development, competitiveness as well as to secure employability. Indeed, everybody should learn till the highest part of learning, which is at a tertiary level. Ironically, at this level, many are unsure to choose an academic programme that would be of their interest and offer good career opportunities.

Choosing an academic programme is crucial and a great challenge as it would tremendously affect one's satisfaction. Failure to choose the right programme, would make one suffers from stress, burn out and thus ruins his/her entire life. Several programmes such as medicine, engineering, law and accounting are on the top list of students' choices. These programmes are highly demanded because the students believed that the programmes assure a good career path, offer lucrative income with great opportunities and prospects. Social groups namely parents, teachers, counsellors and friends also play a significant role in motivating the students. Most often, apart from fulfilling their own choice, the students also strive to fulfil the social groups' expectation.

Accounting is the oldest profession in the world and has always been at the core of every successful programme (Djatej, Chen, Eriksen \& Zhou, 2015). According to Weygand, Kieso and Kimmel (2012), accounting is a language of business that entails a series of events comprising of identifying, recording, classifying and communicating the economic status of an organisation to the interested users. As such, every business needs accountants for survival, sustainable and resilient so that it enables to deal with market's uncertainties, volatility and impropriety. 
Indeed, rapid and massive economy development throughout the world has sparked a massive demand for accountants specifically in the developing countries like Malaysia and Indonesia. Malaysia inspires to be a developed nation with a high-income status in 2020. In realising this aspiration, the country needs 60,000 accountants to fuel the nation's demand (NST, 25 May, 2015). Unfortunately, it is extremely hard to fill the gap in less than 2 years as to date the number of registered professional accountants in the country is only 33,000 people.

Indonesia is facing a similar issue, whereby the number of certified public accountant over the total population ratio is merely $0.0004 \%$ (Pratama, 2017). The country has only 487 public accounting firms with 1,008 Certified Public Accountant (CPA) as registered partners over population of 230 million. In 2014, the Ministry stated that the country had less than 16,000 professional accountants. Nevertheless, more than 226,000 companies in Indonesia require accounting services and thus indicate that there are huge demands and ample opportunities for accountants in domestic work force (Pratama, 2017).

As of now, the number of available accountants has yet to fuel the demands of both nations, namely Malaysia and Indonesia. To overcome this issue, effective strategies should be formulated to entice students choosing accounting programme. Before formulating the strategies, factors that influence student's intention to choose accounting as his/her academic programme should be carefully identified. Theory of Reasoned Action (TRA) predicts two factors namely attitude towards accounting profession and social group influence affect student's intention to choose accounting as academic programme which have been supported by many prior studies (Pratama, 2017; Rababah, 2016; Tang \& Seng, 2016; Djatej et al., 2015; Umar, 2014; Dibabe, Wubie \& Wondmagegn, 2013; Zakaria et al., 2012; Jackling \& Keneley, 2009).

To the researchers' knowledge, almost all the prior studies were conducted in the context of one nation. Dearth of studies has been found examining the issue between two or more nations. As technology and digital enthrall the world to globalisation, internalisation and borderless, hence, it is more becoming if the issue is viewed in a broader context. Since Malaysia and Indonesia are entangled with a similar issue, a comparative study is needed to fill this void at least partially, so that the issue that intertwined these two nations would be resolved simultaneously.

Adopting TRA and emulating prior studies (Pratama, 2017; Rababah, 2016; Djatej et al., 2015; Umar, 2014; Zakaria et al., 2012; Jackling \& Keneley, 2009), the objectives of this study are to decipher attitude towards accounting programme and social group influence on intention to choose accounting as academic programme among Malaysian and Indonesian students.

With regards to this, the paper is organised as follows. First, it starts with introduction and problem statement in section one. Section two reviews the literature before proposing hypotheses. Then it is followed by explanation on methodology in section three. Section four analyses the results of the study. The discussion is in section five that highlights on implications and limitations of the study. Finally, the paper ends up with a conclusion.

\section{Literature Review}

The focus of this study is intention to choose accounting as a choice of academic programme. The intention to choose accounting programme is aligned to the model developed by Ajzen and Fishbein known as the Theory of Reasoned Action.

\subsection{Theory of Reasoned Action}

Originated in the field of social psychology, the Theory of Reasoned Action (TRA) was developed in 1967 by Icek Ajzen and Martin Fishbein. The theory holds that one's intention is affected by his/her attitude towards behaviour. Subjective norms which are akin to social group also influence one's intention which eventually motivates them to perform the behaviour. Hence, the stronger the intention, the more likely is the behaviour will be performed. (Ajzen \& Fishbein, 1980). Figure 1 depicts the model of Theory of Reasoned Action.

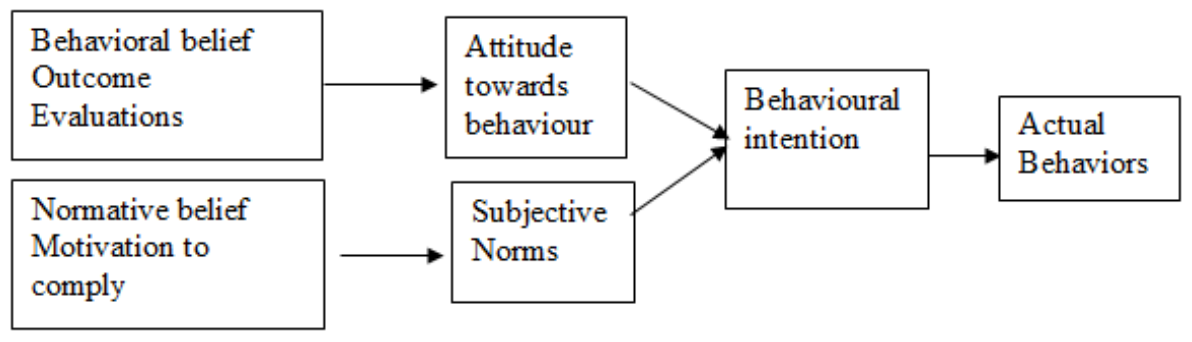

Figure 1. Theory of Reasoned Action (Ajzen \& Fishbein, 1980) 


\subsection{Intention to Choose Accounting as Academic Programme}

Attitudes towards behaviour and social group influence are posited by TRA affect behavioural intention. In the context of this study, behavioural intention is tantamount to one's intention to choose accounting as academic programme. However, attitude towards behaviour is construed to one's attitude towards accounting profession.

\subsection{Attitude towards Accounting Profession}

According to TRA, attitude towards behaviour is a formation of two functions; behavioural belief and outcome evaluation (Ajzen \& Fishbein, 1984). The behavioural belief is one's cognitions that the behaviour leads to certain outcomes. For example, how one believes that accounting profession would provide good prospective. The outcome evaluation is how one evaluates that the probability of the good prospective would be realised from accounting profession.

\subsection{Subjective Norm/Social Group Influence}

TRA postulates that subjective norm which is akin to social group influence is the product of normative belief and motivation to comply (Ajzen \& Fishbein, 1985). The normative belief refers to one believes that social groups namely family, teachers, friends and peers want he/she to choose accounting programme. Motivation to comply on the other hand refers to a situation whereby one is motivated to comply with the expectations of the social groups. In other words, social group influence represents the social clues and pressures received by one before deciding his/her intention.

Multitude empirical studies have adopted TRA model and indicated that attitude towards accounting profession and social groups influence were factors that affected student's choice in choosing accounting as academic programme (Pratama, 2017; Rababah, 2016; Tang \& Seng, 2016; Djatej, 2015; Umar, 2014; Dibabe et al., 2013; Zakaria et al., 2012; Jackling \& Keneley, 2009).

Pratama (2017) adopted TRA model to examine attitudes towards accounting profession and social group influence as determinant factors of student's intention in choosing accounting programme on 365 first year accounting students in a public university in Indonesia. The study found that student's attitude towards accounting profession and social group influence is more likely to affect his or her choice in choosing accounting programme. Results further indicated that students believed career expectation was the highest outcome offered by the profession. Additionally, the student was motivated to comply with family, followed by teacher, friends, society and government in choosing the programme.

Rababah (2016) investigated factors that influence student's intention in choosing accounting as a major course among 340 students from a private university in United Arab Emirates. Results indicated that student's attitude and social group influence were more likely to affect his or her choice in choosing accounting as a major course. Furthermore, the student believed that job prospect was the paramount outcome delivered by the profession, and he/she was more likely motivated to comply with family's expectation, followed by members and peers.

Tang and Seng (2016) examined factors of student's intention in choosing accounting as a major on 240 business students from a Cambodian university. The study indicated that student's attitude in relation to guidance, career expectation, and job opportunities as factors that more likely to influence his/her intention in choosing accounting as a major.

Djatej et al., (2015) explored the relationships between attitude and social group influence on intentions in pursuing accounting as a major on 1207 undergraduate students from three universities in the US by using TRA as an underlying model. Results revealed that student's intention to choose accounting as academic programme was related to his/her attitude towards accounting profession and social group influence. Moreover, the student perceived that reputation of accounting profession delivers the utmost outcome, and parents followed by teachers play a significant role in motivating him/her to choose the academic program.

Umar (2014) conducted a study on factors influence student's intention in choosing accounting programme among 88 students from department of accountancy of Nigerian university. This study also found that attitude and social group influence were more likely to influence intention to choose accounting as an academic programme. The attitude in relation to self-desire, better pay, prestige and prospects were more likely to be the major influential factors. While, the utmost influential social group was parents.

Dibabe et al., (2013) carried out a study on determinant factors of student's intention in choosing accounting as academic programme among 197 students from universities and colleges of business and economic programmes in Ethiopia. Results showed that student's attitude in relation to his or her believed that job responsibility and opportunity offered by the profession stood as the highest factor to affect his/her intention. Additionally, social groups also affected intention of which family was the most influential group.

Zakaria et al, (2012) examined factors that influence student's intention to choose accounting as their academic programme on 340 accounting students in a public university in Malaysia by emulating variables posited by TRA. Results indicated that attitude towards accounting profession with regards to good long-term earnings, exiting profession and advancement opportunities were more likely to influence student's intention to choose accounting programme. Furthermore, the student was more likely to be 
motivated and complied with parents' expectation, followed by teachers, counsellor, friends and peers.

Jackling and Keneley (2009) also adopted TRA to investigate 437 undergraduate students who chose accounting as academic programme at Victorian University in Australia. This study found that attitude in relation to excellent job opportunities and high salary was more likely to be the most influential factors of student's intention. Social group was also a significant factor of which the student was more likely to be motivated and complied with the expectation of his/her parents and relatives.

Adopting variables postulated by TRA and emulating prior studies (Pratama, 2017; Rababah, 2016; Tang \& Seng, 2016; Djatej, 2015; Umar, 2014; Dibabe et al., 2013; Zakaria et al., 2012; Jackling \& Keneley, 2009), hypotheses 1, 2, 3 and 4 are formulated as follow.

H1: Attitude of a Malaysian student towards accounting profession is more likely to affect his/her intention in choosing accounting as academic programme.

$\mathrm{H} 2$ : Attitude of an Indonesian student towards accounting profession is more likely to affect his/her intention in choosing accounting as academic programme.

H3: Social group influence is more likely to affect intention of a Malaysian student in choosing accounting as academic programme.

H4: Social group influence is more likely to affect intention of an Indonesian student in choosing accounting as academic programme.

The proposed model is depicted in Figure 2.

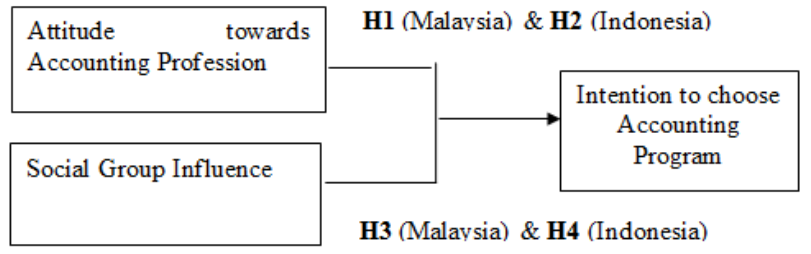

Figure 2. Proposed Model

\section{Methodology}

\subsection{Sample and Data Collection}

The population of this study consisted of first year undergraduate accounting students from one of the Malaysia's public universities and an Indonesia's private university. All samples were generated by the system, of which about 380 out of 420 students were listed as Malaysian samples and 170 out of 202 for Indonesian samples. This amount exceeded the sample size suggested by Krejcei and Morgan (1970), which was 210 and 132 respectively for the same size of population.

The system e-mailed a questionnaire to each respondent. The objectives of the study were stated on the questionnaire. Apart from that, the respondent was assured of the anonymity and confidentiality of which the study was solely meant for research purposes. The respondent was informed to reply within 2 weeks. After 3 weeks, if there was no response, a gently reminder was e-mailed to him/her, emphasizing on the importance of his/her response for the development of accounting communities. Finally, after 4 weeks, a total of 350 responses were received from Malaysian students and 150 responses from Indonesian students, indicating $92.11 \%$ and $88.2 \%$ rate of response respectively for both nations.

\subsection{Questionnaire Development}

The study employed a cross-sectional research design using a self-administered questionnaire adapted from Zakaria et al. (2012) with minimal modifications to suit to both Malaysian and Indonesian contexts. The survey instrument consisted of seven-page questionnaire with two parts. Part A entails respondent's demographic profile that includes gender, age, and prior knowledge of accounting before joining the programme. Part B constitutes of 36 questions which delineate intentions (10 items), behavioural beliefs (12 items), outcome evaluations (12), motivation to comply (5 items) and normative beliefs (5 items). All questions were assessed using seven-point Likert scale.

\subsection{Measurements}

\subsubsection{Intention to Choose Accounting Programme}

Intention to choose accounting programme was measured by respondent's motives for choosing accounting as his/her academic programme. The intention was measured by 10 question items.

\subsubsection{Attitudes towards Accounting Profession}

The attitude towards accounting profession entailed 12 career outcomes. Every respondent was required to indicate his/her behavioural beliefs and outcome evaluations on each of the 12 career outcomes. The 12 career outcomes are good long-term incomes (1), job development (2), job variations (3), opportunity to make contribution (4), flexibility of career options (5), high job security (6), social prestige (7), structured career path (8), exciting profession (9), opportunity to work with numbers (10), broad job opportunities (11) complicated profession (12). Both scores rated for behavioural beliefs and outcome evaluations were multiplied to form the score for attitude towards accounting profession.

\subsubsection{Social Group Influence}

Social group influence is a product of normative belief and motivation to comply. This study entailed 5 social groups that include family, friends, peers, counsellor and teachers, who are perceived to more likely influence 
student's intention in choosing accounting as academic programme. A respondent was required to indicate the extent of his/her beliefs that each social group wants him/her to choose accounting programme. Additionally, he/she was required to assess the probability that he/she is motivated to comply with the expectation of every social group. Finally, both scores of normative beliefs and motivation to comply were multiplied to form the score for social group influence.

\section{Results}

\subsection{Demographic Profiles}

Table 1. Respondents’ Demographic Profile

\begin{tabular}{|c|c|c|c|c|c|}
\hline \multirow{2}{*}{ Profile } & Categories & \multicolumn{2}{|c|}{ MAL } & \multicolumn{2}{c|}{ IND } \\
\hline & & Frequency & \% & Frequency & $\%$ \\
\hline \multirow{2}{*}{ Gender } & Male & 98 & 28.00 & 59 & 39.33 \\
\cline { 2 - 6 } & Female & 252 & 72.00 & 91 & 60.67 \\
\hline Age & 21 & 290 & 82.86 & 104 & 69.33 \\
\hline \multirow{2}{*}{} & 22 & 27 & 7.71 & 22 & 14.67 \\
\hline & 23 & 30 & 8.57 & 20 & 13.33 \\
\hline \multirow{2}{*}{$\begin{array}{c}\text { Accounting } \\
\text { Background }\end{array}$} & Ybove 24 & 3 & 0.86 & 4 & 2.67 \\
\cline { 2 - 6 } & Yes & 213 & 60.86 & 82 & 54.67 \\
\hline
\end{tabular}

Malaysian N=350. Indonesian $\mathrm{N}=150$

Results indicated that Malaysian respondents consisted of more female than male with 242 (71.2\%) and 98 (28.8\%) students respectively. Likewise, Indonesian's respondents also constituted of more female than male with 91 (60.67\%) and 59 (39.33\%) students respectively. In term age, majority of Malaysian's respondents were 21 years old ( 290 or $82.8 \%$ ), followed by 23 years old (30 or $8.6 \%$ ), 22 years old (27 or $7.71 \%$ ) and 3 or $0.86 \%$ of respondents were above 24 years old. Indonesian's respondent showed slightly a similar pattern, of which 104 or $69.33 \%$ of the respondents were 21 years old, followed by 22 years old (22 or 14.67\%), 23 years old (20 or 13.33\%) and above 24 years old ( 4 or $2.67 \%$ ). Prior joining the programme, 213 or $60.7 \%$ of Malaysian's respondents had accounting background, while the remaining 137 or $39.3 \%$ were without accounting background. The results also indicated that more Indonesian's respondents had accounting background as opposed to without accounting background that was 82 (54.67\%) and 68 (45.33\%) respectively. Table 1 depicts respondents' demographic profile for students of Malaysia and Indonesia.

\subsection{Normality Test}

A normality test is ascertained to ensure that data are normally distributed. Results indicated that mean values of underlying variables for Malaysian's respondents were between the range of 4.67 to 5.74, while Indonesian's respondents obtained the scores between 4.19 and 6.23. Kurtosis and skewness values for both Malaysian and Indonesian students were from 0.41 to 0.82 and 0.55 to 0.78 respectively. Both Malaysian and Indonesian students obtained standard deviation score from the lowest of 1.12 to the highest of 1.43 . These values are within normal distribution of -2 and +2 and hence the data are accepted for normal distribution (George \& Mallery, 2010).

\subsection{Descriptive Analyses}

\subsubsection{Attitudes towards Accounting Profession}

Emulating the TRA (Ajzen \& Fishbein, 1980), attitude is derived through two dimensions namely behavioural beliefs (BB) and outcome evaluations (OE). A respondent evaluated behavioural beliefs on a continuum of 1 that is extremely unlikely to 7 , that is extremely likely. The respondent was also required to evaluate outcome evaluation in the continuum of extremely bad (1) to extremely good (7). Later, both behavioural beliefs and outcome evaluations scores were multiplied to form attitudes towards accounting profession value. The results indicated that Malaysian's students obtained the highest score on good long-term income (32.20), followed by job variations (35.73), exciting profession (33.98), job development opportunities (37.44), flexibility of career options (30.57), high job security (37.43), opportunity to work with numbers $(34,10)$, structured career path $(35.16)$, opportunity to make a contribution (34.10), social prestige (32.27), ample working opportunities (38.54) and complicated profession (22.74).

On the other hand, the results indicated that the highest score obtained by Indonesian's student was broad working opportunities (38.54), followed by job development opportunities (37.44), high job security (37.43), flexibility of career options (35.75), job variations (35.73), structured career path (35.16), good long term income (35.10), opportunity to work with numbers (34.10), exciting profession (33.98), social prestige (32.37), opportunity to work with numbers (30.57), and complicated profession (19.06). Table 2 shows behavioural belief (BB), outcome evaluation (OE), attitude (ATT) and ranking based on 12 outcomes from choosing accounting as an academic programme for Malaysian and Indonesian respondents. 
Table 2. Behavioural Belief (BB), Outcome Evaluation (OE) and Attitude (ATT)

\begin{tabular}{|c|c|c|c|c|}
\hline \multirow[t]{2}{*}{ Outcomes } & \multicolumn{2}{|c|}{ Attitude (ATT) (BB x OE) } & \multicolumn{2}{|c|}{ Ranking } \\
\hline & MAL & IND & MAL & IND \\
\hline Good long-term income & $\begin{array}{c}32.20 \\
(5.74 \times 5.61)\end{array}$ & $\begin{array}{c}35.10 \\
(5.93 \times 5.92)\end{array}$ & 1 & 7 \\
\hline Job development & $\begin{array}{c}30.25 \\
(5.47 \times 5.53)\end{array}$ & $\begin{array}{c}37.44 \\
(6.01 \times 6.23) \\
\end{array}$ & 4 & 2 \\
\hline Job variations & $\begin{array}{c}30.90 \\
(5.46 \times 5.66)\end{array}$ & $\begin{array}{c}35.73 \\
(5.83 \times 5.57) \\
\end{array}$ & 2 & 5 \\
\hline Opportunity to make contribution & $\begin{array}{c}28.73 \\
(5.32 \times 5.40)\end{array}$ & $\begin{array}{c}30.57 \\
(5.49 \times 5.57)\end{array}$ & 9 & 10 \\
\hline Flexibility of career options & $\begin{array}{c}29.59 \\
(5.44 \times 5.44)\end{array}$ & $\begin{array}{c}35.75 \\
(5.93 \times 6.03) \\
\end{array}$ & 5 & 4 \\
\hline High job security & $\begin{array}{c}29.75 \\
(5.40 \times 5.51)\end{array}$ & $\begin{array}{c}37.43 \\
(5.99 \times 6.25) \\
\end{array}$ & 6 & 3 \\
\hline Social prestige & $\begin{array}{c}26.83 \\
(5.24 \times 5.12) \\
\end{array}$ & $\begin{array}{c}32.37 \\
(5.63 \times 5.75) \\
\end{array}$ & 10 & 11 \\
\hline Structured career path & $\begin{array}{c}28.78 \\
(5.35 \times 5.38) \\
\end{array}$ & $\begin{array}{c}35.16 \\
(5.97 \times 5.89) \\
\end{array}$ & 8 & 6 \\
\hline Exciting profession & $\begin{array}{c}30.85 \\
(5.49 \times 5.62) \\
\end{array}$ & $\begin{array}{c}33.98 \\
(5.83 \times 5.83) \\
\end{array}$ & 3 & 9 \\
\hline Opportunity to work with numbers & $\begin{array}{c}29.05 \\
(5.33 \times 5.45)\end{array}$ & $\begin{array}{c}34.10 \\
(5.90 \times 5.79)\end{array}$ & 7 & 8 \\
\hline Broad working opportunities & $\begin{array}{c}25.65 \\
(5.11 \times 5.02) \\
\end{array}$ & $\begin{array}{c}38.54 \\
(6.09 \times 6.33) \\
\end{array}$ & 11 & 1 \\
\hline Difficult and intensive profession & $\begin{array}{c}22.74 \\
(4.87 \times 4.67)\end{array}$ & $\begin{array}{c}19.06 \\
(4.55 \times 4.19)\end{array}$ & 12 & 12 \\
\hline
\end{tabular}

\subsubsection{Social Group Influence}

Social group influence is a product of normative beliefs (NB) and motivation to comply (MC) The highest score of social group influence obtained by Malaysian's respondents was family (29.00), followed by teachers (26.00), advisors/counsellors, (25.65) friends (23.66) and peers (21.41). Likewise, Indonesian's students had a similar ranking with Malaysian students but with different score values. The highest score was family (35.24), followed by teachers (26.45), counsellors (23.91), friends (23.27) and peers (21.89). Table 3 illustrates the results of social group influence score of Malaysian and Indonesian respondents.

Table 3. Social Group Influence score of Malaysian and Indonesian Respondents

\begin{tabular}{|c|c|c|c|c|}
\hline Social Group & & \multicolumn{2}{|c|}{ Social Group Influence (NB x MC) } & \\
\hline & MAL & Ranking & IND & Ranking \\
\hline Family & $29.00(5.37 \times 5.40)$ & 1 & $35.24(6.14 \times 5.74)$ & 1 \\
\hline Teachers & $26.00(5.19 \times 5.01)$ & 2 & $26.45(5.28 \times 5.01)$ & 2 \\
\hline Advisor/ counsellor & $25.65(5.07 \times 5.06)$ & 3 & $23.91(4.78 \times 4.87)$ & 3 \\
\hline Friends & $23.66(5.11 \times 4.63)$ & 4 & $23.27(4.87 \times 4.91)$ & 4 \\
\hline Peers & $21.41(4.90 \times 4.37)$ & 5 & $21.89(4.60 \times 4.76)$ & 5 \\
\hline
\end{tabular}

\subsubsection{Intention}

The results of Malaysian and Indonesian respondents score for intention were between 4.52 to 5.64 and 4.63 to 6.03 respectively. 


\subsection{Data Analysis}

This study adopted Smart Partial Least Square (PLS) version 3.0 to assess the research model by assessing the parameters in the inner and outer model (Ringle, Wende \& Will, 2005). For this proposed research model, the PLS-SEM algorithm converged after 14 iterations, indicating that the data for both nations were normal. The PLS path modelling was adopted for this study with a path weighing scheme for the inside approximation of 200 resampling. This was to attain standard errors of the estimate. Emulating Anderson and Gerbing (1988), the PLS was assessed via two evaluations namely measurement and structural models. Measurement model was evaluated in the first stage and the structural model was assessed in the second stage.

\subsection{Assessment of a Measurement Model}

In the measurement model, the data are assessed for reliability and validity. The reliability assessment is evaluated through two assessments namely reliability analysis of internal consistency and composite reliability. The validity assessment is also conducted by two assessments that are convergent and discriminant validity.

\subsection{Reliability Analysis}

According to Sekaran and Bogie (2010), reliability analysis is to assess whether items are consistently represented the constructs they are measured. Results indicated that Cronbach alpha values of all constructs for
Malaysian and Indonesian respondents were between 0.88 to 0.93 . The scores surpass the value of 0.6 recommended by Sekaran and Bogie (2010), indicating that items are almost represented the measured constructs.

\subsection{Composite Reliability}

Hair, Anderson, Tatham \& Black (2012) suggested that Cronbach's alpha should be replaced by composite reliability, for evaluating the internal consistency in PLS-SEM. According to Bagozi and Yi (1988), a preferable score of composite reliability should be higher than 0.7 and for exploratory study, a value of 0.6 is considered acceptable. The results indicated that all composite reliability scores for both nations were higher than 0.7, indicating acceptable levels of internal consistency has been demonstrated among all reflective latent constructs.

\subsection{Convergent Validity}

Convergent validity is assessed by two measurements namely factor loading, and average variance extracted (AVE). Items with factor loading of lower than 0.5 were eliminated from the model as suggested by Chin, Marcolin and Newsted (1997) and only items with loadings above 0.5 were in the final model. The AVE values were greater that the acceptable threshold score of 0.5 (Bagozzi \& Yi, 1988), and therefore the requirements of convergent validity has been fulfilled. Table 4 depicts the results of the measurement models for Malaysian and Indonesian respondents.

Table 4. Measurement Models for Malaysian and Indonesian Respondents

\begin{tabular}{|c|c|c|c|c|c|c|c|c|c|}
\hline Construct & Item & \multicolumn{2}{|c|}{ Loadings } & \multicolumn{2}{|c|}{ Cronbach } & \multicolumn{2}{|c|}{ CR } & \multicolumn{2}{|c|}{ AVE } \\
\hline \multirow{12}{*}{ ATT } & & MAL & IND & MAL & IND & MAL & IND & MAL & IND \\
\hline & ATT1 & 0.694 & 0.752 & 0.931 & 0.932 & 0.93 & 0.942 & 0.548 & 0.596 \\
\hline & ATT2 & 0.662 & 0.796 & & & & & & \\
\hline & ATT3 & 0.742 & 0.793 & & & & & & \\
\hline & ATT4 & 0.764 & 0.811 & & & & & & \\
\hline & ATT5 & 0.769 & 0.790 & & & & & & \\
\hline & ATT6 & 0.728 & 0.791 & & & & & & \\
\hline & ATT7 & 0.675 & 0.773 & & & & & & \\
\hline & ATT8 & 0.709 & 0.729 & & & & & & \\
\hline & ATT9 & 0.882 & 0.766 & & & & & & \\
\hline & ATT10 & 0.771 & 0.648 & & & & & & \\
\hline & ATT11 & 0.720 & 0.823 & & & & & & \\
\hline & SN1 & 0.722 & 0.608 & 0.848 & 0.850 & 0.846 & 0.895 & 0.525 & 0.634 \\
\hline & SN2 & 0.741 & 0.893 & & & & & & \\
\hline SG & SN3 & 0.713 & 0.854 & & & & & & \\
\hline & SN4 & 0.626 & 0.826 & & & & & & \\
\hline & SN5 & 0.809 & 0.769 & & & & & & \\
\hline & INT1 & 0.883 & 0.851 & 0.879 & 0.881 & 0.878 & 0.913 & 0.645 & 0.678 \\
\hline INT & INT2 & 0.853 & 0.818 & & & & & & \\
\hline IN & INT3 & 0.767 & 0.875 & & & & & & \\
\hline & INT4 & 0.696 & 0.835 & & & & & & \\
\hline & INT5 & - & 0.729 & & & & & & \\
\hline
\end{tabular}


Table 5. Discriminant Validity of Malaysian and Indonesian Respondents

\begin{tabular}{|c|c|c|c|c|c|c|}
\hline & \multicolumn{2}{|c|}{ ATT } & \multicolumn{2}{c|}{ INT } & \\
\hline & MAL & IND & & IND & \\
\hline ATT & 0.740 & 0.772 & MAL & 0.823 & MAL \\
\hline INT & 0.583 & 0.576 & 0.803 & 0.591 & 0.725 \\
\hline SN & 0.543 & 0.533 & 0.596 & IND & 0.796 \\
\hline
\end{tabular}

\subsection{Discriminant Validity}

Discriminant validity is to ensure that the constructs are different and do not relate to each other. According to Fornel and Larker (1981), the discriminant validity would be fulfilled if the "square root" of AVE of each latent variable is greater than the correlations among the latent constructs. The results show that all values were below a threshold of 0.85 as suggested by Kline (2011), indicating that there is no issue of multi-collinearity of which the constructs are not related to each other and hence the discriminant validity is well established. These values are shown in 'bold' numbers in Table 5. Table 5 depicts discriminant validity of Malaysian and Indonesian Respondents.

\subsection{Structural Model}

After data had fulfilled all criteria for reliability and validity requirements, the data were further assessed in a structural model. The structural model indicates that the correlation between constructs through the values of path coefficient and $R^{2}$ (Sang \& Bogie, 2010). As suggested by Hair, Hollingsworth, Randolph and Chong (2017), the study adopted a Bootstrap analysis using 5000 resampling to test the hypotheses. A simple rule of thumb, the cut-off critical t-value is 1.96 for a two-sided test with significant level of $5 \%$. Any t-values that is greater than the cut-off value indicates that the path coefficients are significantly different from 0 .

\subsection{Malaysian Respondent}

Emulating Tenenhaus, Vinz and Lauro (2005), a global fit measure for path modelling namely global fit measure (GoF), was used to assess the validity of a PLS model. The general baseline values are GoFsmall = 0.1, GoFmedium =
0.25 and GoFlarge $=0.36$. Results indicated that the value of GoF obtained was 0.47, which exceeded the value suggested by Akter, D'Ambra and Ray (2011). Additionally, the results showed that 45.0 percent of student's intention to choose accounting as an academic programme was explained by his/her attitude towards accounting profession and social group influence $\left(R^{2}=45.0 \%\right)$. The results also showed that all $\mathrm{t}$-values exceeded the cut-off critical value of 1.96 , indicating a significant value difference from 0 . In other words, attitude towards accounting profession has a significant relationship with intention to choose accounting programme $(\beta=0.368 `, p<0.01)$. Additionally, social group influence has also a significant relationship with intention to choose accounting programme $(\beta=0.396$, $p<0.01$ ). Table 6 and figure 2 depict the results of the structural model from the PLS output.

\subsection{Indonesian Respondents}

The GoF value was high that is 0.403 which is greater than the general baseline values of GoFsmall $=0.1$, GoFmedium $=0.25$ and GoFlarge $=0.36$ suggested by Akter, et al., (2011). Results indicated that the $R^{2}$ is 34.10 percent. This shows that 34.10 percent of intention to choose accounting as an academic programme was determined by attitude towards accounting profession and social group influence. The results also show that all t-values exceeded the cut-off value critical value of 1.96, indicating a significant value difference from 0 . In other words, attitude towards accounting profession has a significant relationship with intention to choose accounting programme $(\beta=0.313, p<0.01)$. Additionally, social group influence has also a significant relationship with intention to choose accounting programme $(\beta=0.375, p<0.01)$. Table 6 and figure 3 depict the results of the structural model from the PLS output. 
Accounting as a Choice of Academic Programme:

A Comparative Study between Malaysian and Indonesian First-year Under-graduate Accounting Students

Table 6. Path Coefficient and Hypotheses Testing for Malaysian and Indonesian Respondents

\begin{tabular}{|c|c|c|c|c|c|c|c|c|c|}
\hline Hypothesis & Relation & Beta & SE & T-Value & Decision & \multicolumn{2}{|c|}{$\boldsymbol{R}^{2}$} & \multicolumn{2}{|c|}{ GoF } \\
\hline & & & & & & MAL & IND & MAL & IND \\
\hline H1 & ATT -> INT & $0.368^{* *}$ & 0.061 & 6.051 & Supported & 0.450 & 0.341 & 0.467 & 0.403 \\
\hline H2 & ATT -> INT & $0.313^{* *}$ & 0.073 & 4.280 & Supported & & & & \\
\hline H3 & SN -> INT & $0.396^{* *}$ & 0.063 & 6.286 & Supported & & & & \\
\hline H4 & SN -> INT & $0.375^{* *}$ & 0.075 & 5.015 & Supported & & & & \\
\hline
\end{tabular}

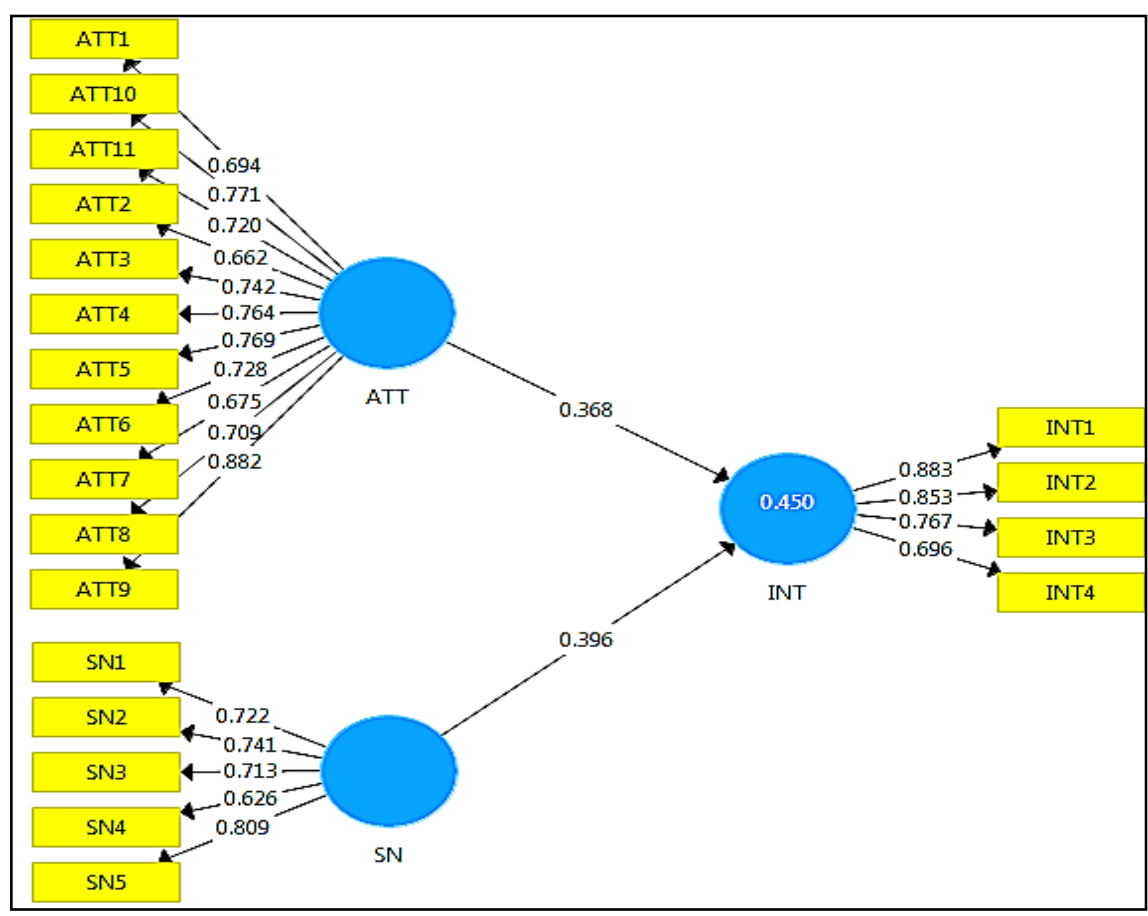

Figure 2. The Structural Model of Malaysian Respondents

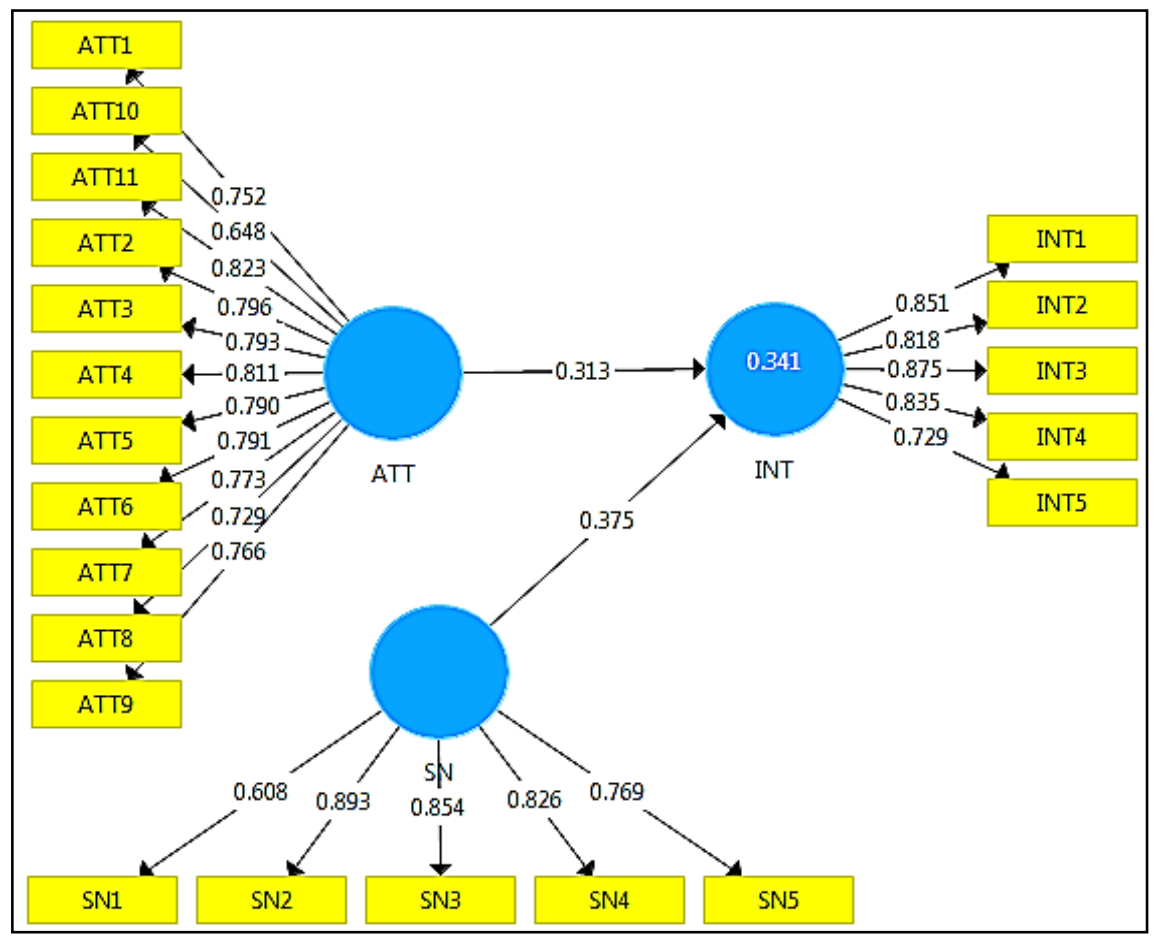

Figure 3. The Structural Model of Indonesian Respondents 


\section{Discussion}

Hypothesis 1 proposes that attitude of a Malaysian student towards accounting profession is more likely to affect his/her intention in choosing accounting as academic programme. The results support hypothesis $1(\beta=0.368, p$ $<0.01$ ) and concur with the work of prior studies (Pratama, 2017; Rababah, 2016; Djatej et al., 2015; Umar, 2014; Zakaria et al., 2012: Jackling \& Keneley, 2009) that the more positive is the student's attitude towards accounting profession, the more likely is his/her intention to choose accounting programme.

Hypothesis 2 proposes that attitude of an Indonesian student towards accounting profession is more likely to affect his/her intention in choosing accounting as academic programme. The results support hypothesis $2(\beta=0.313, p$ $<0.01$ ) and in tandem with prior studies (Pratama, 2017; Rababah, 2016; Djatej et al., 2015; Umar, 2014; Zakaria et al., 2012; Jackling \& Keneley, 2009) that the more positive is the student's attitude towards accounting profession, the more likely is his/her intention to choose accounting as academic programme. However, Malaysian students exhibit a higher magnitude of effect over Indonesian students on attitude towards accounting profession.

Hypothesis 3 proposes that social group influence is more likely to affect intention of a Malaysian student in choosing accounting as academic programme. The results support hypothesis $3(\beta=0.396, p<0.01)$ and is consistent with prior studies (Pratama, 2017; Rababah, 2016; Djatej et al., 2015; Umar, 2014; Zakaria et al., 2012; Jackling \& Keneley, 2009), of which, the more the student's perceived that the social groups want him/her to choose accounting programme, the more likely he/she is motivated to comply to their expectation.

Hypothesis 4 proposes that social group influence is more likely to affect intention of an Indonesian student in choosing accounting as academic programme. The results support hypothesis $4(\beta=0.375, p<0.01)$ and in tandem with prior studies (Pratama, 2017; Rababah, 2016; Djatej et al., 2015; Umar, 2014; Zakaria et al., 2012; Jackling \& Keneley, 2009), of which, the more the student's perceived that the social groups want him/her to choose accounting programme, the more likely he/she is motivated to comply to their expectation. Likewise, Malaysian students exhibit a higher magnitude of effect over Indonesian students on social group influence.

\subsection{Management Implication}

The results provide implications to policy makers, higher educational institutions and accounting professional bodies to formulate policies and strategies that emphasize on the prospects of the profession so that students would have positive attitudes towards accounting profession. This can be done by stressing on the lucrative rewards offered by the accounting profession which is on par or even better when compared with other professions. Furthermore, the students should be informed that the notion of being in the profession is the ability to serve and contribute to the nations.

The results also provide an implication that aggressive promotions on accounting career talks should be carried out to reach high school students, parents, counsellors, teachers, students and the public at large. The career talks can be conducted through various channels such as seminars, high schools out-reach, road tours within the countries (Malaysia and Indonesia), and on the website. The purpose of accountancy career talks is to disseminate relevant information on the role, function, prospects and a better understanding of the profession. These programmes would serve as a platform, not only for students but parents and teachers as well and thus enable them obtaining first-hand information on accounting career paths.

\subsection{Theoretical Implication}

The results provide theoretical implications to the body of knowledge of academic literature on the effect of attitude towards accounting profession and social group influence on intention to choose accounting as academic programme. In other words, the study supports the Theory of Reasoned Action (Azjen \& Fishbein, 1980) that attitude towards behaviour and social group influence affect behavioural intention. The study also supports previous studies that examined the same relationship of the proposed variables (Pratama, 2017; Rababah, 2016; Tang \& Seng, 2016; Djatej, 2015; Umar, 2014; Dibabe et al., 2013; Zakaria et al., 2012; Jackling \& Keneley, 2009). As such, apart from supporting the theoretical works and literatures the study enhances the understanding of students' intention to choose accounting as their academic programme.

\subsection{Limitations and Suggestions for Future Research}

Despite this study supports several theoretical and previous study works, there are few limitations that need to be highlighted. The first limitation noted is that respondents of this study are from developing nations namely Malaysia and Indonesia. These two nations are situated next to another, practiced similar culture, values and customs and hence they are more likely to possess similar traits of attitude. Thought and mind set of social groups are also more likely indifferent which lead to high similarity in the results. To overcome this matter, future studies are suggested to examine the issue between developing and developed nations. This is because people from developed nations are highly exposed to the latest development and technology, and thus lead to differences in thought and mind set between the nations. The differences would be interesting to be explored and not 
impediments to be confronted.

The study is a quantitative approach, whereby data are collected through survey. In this context, respondents are required to answer structured questions. They are denied from expressing their views on what influence their intention to choose accounting programme. To overcome this methodological issue, a qualitative study is suggested to be conducted, whereby the respondents can freely express their own views regarding to their intention, without any restrictions imposed.

\section{Conclusions}

The study indicates that attitudes in relation to incentives and prospects offered by the accounting profession were more likely to influence intention to choose accounting programme. The most incentive that entices Malaysian students was good long-term income, while Indonesian students were enticed by broad working opportunities. Results for both nations indicated that social group influence played a significant role in motivating the students' intention. Both Malaysian and Indonesian students were more likely to rely on parents, followed by teachers, counsellor, friends and peers. Additionally, Malaysian students exhibited high magnitude of effects over Indonesian students for both variables. These discoveries provide useful insights to policy makers, higher institutional education and accounting professional bodies to formulate policies that emphasise on the appealing incentives and prospects of an accounting profession. Additionally, aggressive promotions should be conducted to expose the accounting programme to high school students, parents, teachers, counsellors and the public at large. This can be done through talks, seminars, media, social media, and road-tour within the nations (Malaysia and Indonesia). All these initiatives would fascinate more students to choose accounting programme that would advertently generate many accountants to serve the nations. Consequently, the countries' economy will be accelerated and thus expedited the aspirations of becoming full developed nations in due time.

\section{Acknowledgements}

The authors would like to thank the students from Universiti Teknologi MARA Kelantan Campus and Universitas Swadaya Gunung Jati who participated in the study. They also wish to express their gratitude towards Institute of Quality and Knowledge Advancement (InQKA), Universiti Teknologi MARA for providing continuous support in ensuring the publication of this research possible.

\section{REFERENCES}

[1] Ajzen, I. and Fishbein, M. (1980), Understanding attitudes and predicting social behaviour. Englewood Cliffs, New Jersey: Prentice-Hall.

[2] Akter, S., D’Ambra, J., and Ray, P. (2011), Trustworthiness in Health information services: An assessment of a hierarchical model with mediating and moderating effects using partial least squares (PLS). Journal of the American Society for Information Science and Technology, 62, 100-116.

[3] Chin, W. W. (1998), The partial least squares approach for structural equation modeling. In G. A. Marcoulides (Ed.), Modern methods for business research. Mahwah, New Jersey: Lawrence Erlbaum Associates.

[4] Dibabe, T. M, Wubie, A.W. and Wondmagegm, G.A. (2015), Factors that affect students' career choice in Accounting: A case of Bahir Dar University students. Research Journal of Finance and Accounting, 6(5), 146-153.

[5] Djatej, A., Chen, Y. Eriksen,S. and Zhou,D. (2015), Understanding students' major choice in accounting: An application of the theory of Reasoned Action. Global Perspective of Accounting Education, 12, 53-72.

[6] Faul, F., Erdfelder, E., Buchner, A., and Lang, A.G. (2009), Statistical power analyses using G*Power 3.1: Tests for correlation and regression analyses. Behavior Research Methods, 41, 1149-1160.

[7] Fishbein, M., Ajzen, I. (1975), Belief, Attitude, Intention and Behaviour: An Introduction to Theory and Research. Reading: Addison-Wesley.

[8] Fornell, C. G., and Larcker, D. F. (1981), Evaluating structural equation models with unobservable variables and measurement error. Journal of Marketing Research, 18(1), 39-50.

[9] George and Malery (2010). SPSS for Windows Step by Step: A Simple Guide and Reference, 17.0 update (10a ed.) Boston: Pearson. What is the acceptable range of skewness and kurtosis... Available from: https://www.researchgate.n et/post/What_is_the_acceptable_range_of_skewness_and kurtosis_for_normal_distribution_of_data [accessed Aug 8, 2017].

[10] Hair, J., Hollingsworth, C.L., Randolph, A.B., and Chong,A. (2017), An updated and expanded assessment of PLS-SEM in information systems researce. Industrial Management \& Data Systems, 117(3), 442-458.

[11] Hair, J. F., Hult, T. M., Ringle, C. M., and Sarstedt, M. (2014), A Primer on Partial Least Square Structural Equation Modeling (PLS-SEM). Thousand Oaks, CA: Sage Publications.

[12] Jackling, B. and Keneley, M. (2009), Influences on the supply of accounting graduates in Australia: A focus on international students. Accounting and Finance, 49, 141159. 
[13] Kline, R.B. (2011), Principles and Practice of Structural Equation Modeling. New York: Guilford Press.

[14] Krejcei, R.V. and Morgan, D.W. (1970), Determining sample size for research activities. Educational and Psychological Measurement, 30, 607-610.

[15] Malaysia needs 60,000 accountants by 2020. NST May 25, 2015.

[16] Pratama, A. (2017), Factors Affecting Students’ Learning Interest in an Accounting Study Programme: A Study in Bandung City, West Java, Indonesia. Review of Integrative Business and Economics Research, 6(2), 295-311.

[17] Rababah, A., (2016), Factors influencing the students' choice of accounting as a major: The case of $\mathrm{X}$ university in United Arab Emirates. International Business Research, 9(10), 25-32.

[18] Sekaran, U. and Bougie, R. (2010), Research methods for business: A skill building approach, London:Wiley.

[19] Tang, L.C. and Seng, C. (2016), Factors influence students' choice of accounting major in Cambodian universities. Asian Review of Accounting, 24(2), 231-251.

[20] Umar, I. (2014), Factors influencing students’ career choice in Accounting: The case of Yobe State University. Research Journal of Finance and Accounting, 5(17). 59-62

[21] Zakaria, M. Wan Fauzi, W.N.A, and Hasan, E. J. (2012), Accounting as a choice of academic program. Journal of Business Administration Research, 1(1), 43-52. 